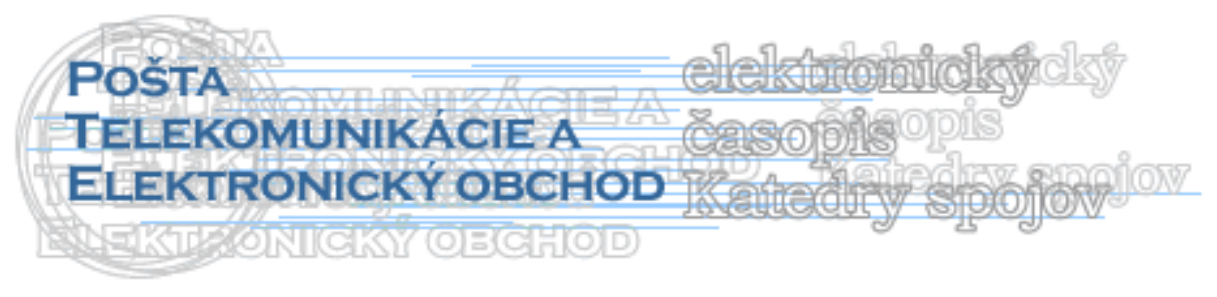

\title{
METÓDY HODNOTENIA ÚSPEŠNOSTI CRM SYSTÉMOV V PODNIKOCH
}

\author{
Peter Mišák, Jana Šujanová*
}

\section{Úvod}

Základným problémom dnešných podnikov nie je nedostatok tovarov, ale nedostatok zákazníkov. Väčšina svetových výrobných odvetví dokáže vyrobit' ovel'a viac, ako svetoví spotrebitelia dokážu kúpit'. Takto sa do popredia dostáva marketing a s ním spojená orientácia na zákazníka - na jeho potreby a požiadavky, na dlhodobo prospešné vzt’ahy s ním. Všetky aktivity a procesy súvisiace s touto problematikou pokrývajú systémy riadenia vzt'ahov so zákazníkmi (Customer Relationship Managemet - CRM), ktoré sa dostávajú v poslednom období významne do popredia.

Implementovaním CRM však aktivity podniku v tejto oblasti zd’aleka nekončia. Práve naopak - pozitívne výsledky CRM prinesie iba vtedy, ked' bude neustále využívaný, aktualizovaný a prispôsobovaný meniacim sa podmienkam a uživatel'om. Každého manažéra podniku, ktorý implementuje CRM bude určite zaujímat' jeho prínos vo vzt'ahoch k zákazníkoch, k podpore predaja a pod. Existuje niekol'ko nástrojov a metód pre meranie efektívnosti implementácie a fungovania CRM systémov podnikoch. Niekol'ko z nich bude predmetom aj tohto príspevku.

\section{Customer Relationship Managemet}

Zo štúdia existujúcich definícii CRM, môžeme všeobecne povedat', že systém CRM sa vyznačuje najmä dlhodobým vytváraním a udržiavaním obojstranne prospešných vzt'ahov medzi firmou a zákazníkmi, počas ktorých dochádza k uspokojovaniu individuálnych potrieb zákazníkom. Platí tiež, že implementácia systému CRM je záležitost' celej spoločnosti, všetkých jej zamestnancov, ktorá sa prejaví aj v podnikovej stratégii.

Samotné riadenie vzt’ahov so zákazníkmi je postavené na 4 pilieroch:

- l'udia,

- procesy,

- technológie,

- dáta [12].

\footnotetext{
* Ing. Peter Mišák, doc. Ing. Jana Šujanová, CSc.

Ústav priemyselného inžinierstva, manažmentu a kvality, Materiálovotechnologická fakulta Trnava, Slovenská technická univerzita Bratislava, Paulínska 16, 91724 Trnava tel.: +421335511033, mobil: +421903703262, fax: +421335511758

e-mail: peter.misak@stuba.sk; jana.sujanova@stuba.sk
} 
Samotné CRM prechádza viacerými fázami. Jan Dohnal vo svojej publikácii definuje 4 fázy CRM systémov:

1. oslovenie zákazníka (Engage) - dodávatel'ský podnik identifikuje, vyberá a chce zaujat' práve tých zákazníkov, ktorým má zmysel produkty a služby poskytnút'. Ide o prvý kontakt s potenciálnym zákazníkom, tzv. pre-sale aktivity. Patrí sem všetko, čo sa týka štandardných marketingových aktivít.

2. obchodná transakcia (Transact) - dodávatel' usiluje o kontakt. V tejto fáze sa odohráva príprava a uzavretie kontraktu.

3. plnenie objednávok (Fulfill) - dodá sa výrobok, resp. služba. Patrí sem:

- všetky logistické aktivity spojené s dodávkou výrobkov a služieb, teda všetko, čo je náplňou práce obchodníkov, vrátane dohl'adu nad vystavením faktúr a registráciou platieb,

- systematická komunikácia dokazujúca, aké d’alšie výrobky a služby môže zákazník od dodávatel'skej firmy získat'.

4. zákaznícky servis (Support) - dodávatel' podporuje implementačné a inštalačné aktivity týkajúce sa dodaného produktu, buduje lojalitu zákazníka. V tejto fáze podnik:

- poskytuje servisné aktivity súvisiace so záručnými službami,

- pokračuje v ponúkaní d’alších komplementárnych produktov a služieb,

- posilňuje lojalitu zákazníkov, prehlbuje diferencovaný prístup k zákazníkovi, aby ponúkané produkty a služby predstavovali čo najväčšiu pridanú hodnotu pre zákazníka [3].

\section{Hodnotenie úspešnosti CRM systémov v podnikoch}

Najlepším spôsobom ako zistit', aký vel'ký má CRM pre podnik prínos a význam, je hodnotenie úspešnosti implementácie CRM.

Pri vyhodnocovaní akéhokol’vek projektu nás vždy zaujíma jeho finančná stránka (návratnost') - ROI. Pre zlepšenie a meranie úspešnosti implementácie CRM je však možné použit' aj d'alšie faktory, metriky a smernice:

1. Výkonové metriky - CRM by mal vyt' meraný na základe ciel'ov, ktoré boli vytýčené pred jeho implementáciou. Ide napr. o zefektívnenie práce a znížení nákladov pri zavedení call-centier, kratšie časy odpovedania zákazníkom, zvýšenie cyklov vývoja výrobkov, zníženie chýb pri preprave a fakturácii a pod. [9].

2. Implementácia CRM krok za krokom - organizácie by mali implementovat' systém po krokoch. Za každým krokom by malo nasledovat' meranie dosiahnutia vytýčených ciel'ov. Mnoho podnikov si zadá na počiatku mnoho požiadaviek a ciel'ov. To si vyžaduje niekol'koročný proces.

3. Zefektívnenie obchodných procesov - význam tohto zefektívnenia je jasný najmä v podnikoch, ktoré predávajú svoje výrobky prostredníctvom distribútorov. Tu je dôležité si určit', či títo sú skôr v postavení zákazníka alebo partnera, ktorý zákazník patrí ktorému obchodníkovi a pod.

4. Zvýšenie ziskovosti zákazníka - jedným z faktorov merania úspešnosti CRM by malo byt' meranie zákazníckej lojality a vernosti. Príliš často je snaha podnikov zameraná na získanie nových zákazníkov, ako na zvýšenie podielu nákupov stálych zákazníkov. Vyššia lojalita pritom znamená zníženie nákladov na akvizície nových zákazníkov. Organizácie by teda mali v rámci merania úspešnosti CRM použit' aj metriky celoživotnej hodnoty zákazníka [10]. 


\section{Prehl’ad existujúcich metód a metodík hodnotenia úspešností systémov CRM}

Existuje množstvo štúdií, ktoré popisujú postupy implementácie systémov CRM do podnikovej praxe. Implementácia takýchto systémov je však len prvým krokom. Každého manažéra musí zaujímat', ako daný systém funguje, či prináša pozitívne výsledky vo forme akvizície nových zákazníkov, resp. udržania existujúcich zákazníkov, ul'ahčuje prácu l’ud'om, ktorý so zákazníkmi pracujú a pod.

V praxi existuje niekol'ko metód a metodík, ktoré umožňujú takéto hodnotenie. Každá z týchto metód sa zameriava na iný uhol pohl'adu a skúma vplyv iných faktorov na CRM. Medzi takéto metódy a metodiky možno zaradit':

- Identifikácia úrovne CRM podl'a P. Kopřivu

- CRM Maturity Model

- $C R M$ Scorecard

- Model pre hodnotenie efektívnosti CRM podla autorov Kim, Suh a Hwang

- Metodika merania CRM v organizáciách podl'a autorov Storbacka a Lehtinen

- Metóda hodnotenia CRM - CRMBodyCheck

- Customer Relation Analysis Complex Kit (CRACK) - Model merania úrovne CRM

- ostatné metódy:

o návratnost' investície (ROI)

o rentabilita nákladov (ROC)

o rentabilita tržieb (ROS)

o zisk na zamestnanca (EMP)

o tržby na zamestnanca (EMS)

o Metóda kvalifikácie rozvojových schopností

\section{Identifikácia úrovne CRM podl’a P. Kopřivu}

Identifikácia úrovne CRM je prvým krokom pri d’alšom skúmaní, príp. inovovaní systému CRM. Touto identifikáciou sa zaoberali na Fakulte informatiky a statistiky VŠE v Prahe.

Pre identifikáciu úrovne bola zvolená škála 5 úrovní. Každá úroveň je charakterizovaná svojimi znakmi, ktoré slúžia ako pre samotnú identifikáciu podniku k aktuálnej úrovni CRM. Ide však o empirické priradenie a preto nemusí byt' vždy úplne presné. Avšak jeho vel'kou výhodou je jednoduché a praktické použitie.

Chaotická úroveň CRM zodpovedá podniku, ktorý nemá primárny záujem na riadení vzt'ahov so zákazníkmi. Akvizičná činnost' takéhoto podniku spočíva v ponuke svojich služieb. Podnik sa väčšinou nijakým spôsobom nezasadzuje o predíženie vzt’ahu so zákazníkom a o maximalizáciu hodnoty vzt’ahu so zákazníkom.

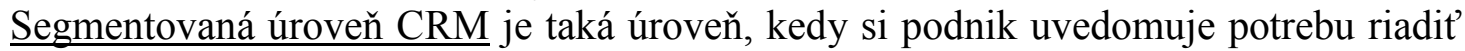
vzt’ah so zákazníkmi a robí základné kroky pre takéto riadenie.

Centrická úroveň CRM rieši problematiku redundancie a trieštenia informácií o zákazníkovi. Dopad vyriešenia tohto problému na podnik je úplne zásadný. Ktokol'vek v podniku, kto je v nejakom vzt’ahu so zákazníkom, má totožné informácie o zákazníkovi ako ostatní zamestnanci. Jeho rozhodovanie je teda podložené aktuálnymi informáciami. Dôsledkom je jednotné vystupovanie voči zákazníkovi nielen z procesného hl'adiska (ako v segmentovanej úrovni CRM), ale taktiež z vecného hl'adiska.

Individualizovaná úroveň CRM zaist'uje sledovanie individuálnych potrieb každého zákazníka. Každý zákazník má svojho osobného správcu. Podnik upravuje svoje správanie v závislosti na konkrétnych potrebách, zvyklostiach a vlastnostiach zákazníka. Zákazník má 
istotu, že podnik k nemu bude vždy pristupovat' sofistikovane a predovšetkým ako partner. Táto úroveň prináša možnost' maxi maximalizácie hodnoty vzt’ahu so zákazníkom.

Globálne individualizovaná úroveň CRM rozširuje individualizované správanie podniku k zákazníkovi do všetkých lokalít, kde podnik pôsobí. Zákazník má istotu, že podnik $\mathrm{k}$ nemu bude pristupovat' jednotne v ktorejkol'vek lokalite na svete [6].

\section{CRM Maturity Model}

Model zrelosti CRM predstavuje súbor kritérií, ktoré sa vyhodnocujú a na tomto základe sa prirad’uje konkrétny stupeň zrelosti systému riadenia vzt’ahov so zákazníkmi. Názorne je tieto stupne, kritéria ako aj konkrétne príklady niektorých firiem vidiet' v nasledujúcej tabul'ke:

Tab. 1 - Hodnotenie spoločností použitím Gartnerovho profilu zrelosti CRM [2]

\begin{tabular}{|c|c|c|c|c|}
\hline & Stupeň & Názov & Popis & Príklady \\
\hline \multirow[b]{2}{*}{ Excelentné } & 6 & Maximum & $\begin{array}{l}\text { Teoreticky najvyšší } \\
\text { možný stupeň }\end{array}$ & \\
\hline & 5 & Popredný & $\begin{array}{l}\text { Popisuje organizácie, } \\
\text { ktoré sú vo svojej } \\
\text { podstate zákaznícky } \\
\text { orientované a pravidelne } \\
\text { obnovujú tieto schopnosti }\end{array}$ & \\
\hline \multirow{3}{*}{ Zlepšujúce sa } & 4 & Optimalizačný & $\begin{array}{l}\text { Popisuje organizácie, } \\
\text { ktoré nielen rozvíjajú } \\
\text { svoju orientáciu na } \\
\text { zákazníka, ale ju aj } \\
\text { aktívne integrujú do } \\
\text { svojich každodenných } \\
\text { činností }\end{array}$ & $\begin{array}{l}\text { Compaq, } \\
\text { Dow }\end{array}$ \\
\hline & 3 & Profesionálny & $\begin{array}{l}\text { Popisuje organizácie, } \\
\text { ktoré majú } \\
\text { implementovanú } \\
\text { základnú orientáciu na } \\
\text { zákazníka - boli } \\
\text { implementované základné } \\
\text { atribúty CRM }\end{array}$ & Wells Fargo \\
\hline & 2 & Rozvíjajúci sa & $\begin{array}{l}\text { Popisuje organizácie, } \\
\text { ktoré sa vyznačujú } \\
\text { základnou orientáciou na } \\
\text { zákazníka, zväčša } \\
\text { prebraný systém }\end{array}$ & $\begin{array}{c}\text { BMC } \\
\text { Software }\end{array}$ \\
\hline \multirow[t]{2}{*}{ Slabé } & 1 & Informovaný & $\begin{array}{l}\text { Popisuje organizácie, } \\
\text { ktoré sa prezentujú } \\
\text { niekol'kými znakmi } \\
\text { zákazníckej orientácie, } \\
\text { vykonáva plánovanie } \\
\text { a zvažovanie CRM }\end{array}$ & \\
\hline & $\mathbf{0}$ & Nulový bod & $\begin{array}{l}\text { Žiadne aktivity týkajúce } \\
\text { sa CRM }\end{array}$ & \\
\hline
\end{tabular}




\section{CRM Scorecard}

Balanced Scorecard (BSC) je manažérsky systém, metodika riadenia, ktorá umožňuje organizáciám objasnit' ich víziu a stratégiu a preniest' ich do akcie. Pri plnom rozvinutí Balanced Scorecard transformuje strategické plánovanie $\mathrm{z}$ akademických príkladov do nervového centra podniku. Nevyhnutným predpokladom implementácie Balanced Scorecard je jasné porozumenia vízii a stratégii organizácie [13].

CRM Scorecards sú jednoduché predpripravené dokumenty, ktoré umožňujú podniku uvedomit' si svoje prednosti a nedostatky priradením hodnoty každému aspektu CRM vzt'ahov a tým uprednostnit' určité aspekty voči ostatným. Najčastejšie je táto metodika realizovaná prostredníctvom softvérových riešení a programov, ktoré zadané informácie automaticky vyhodnotia.

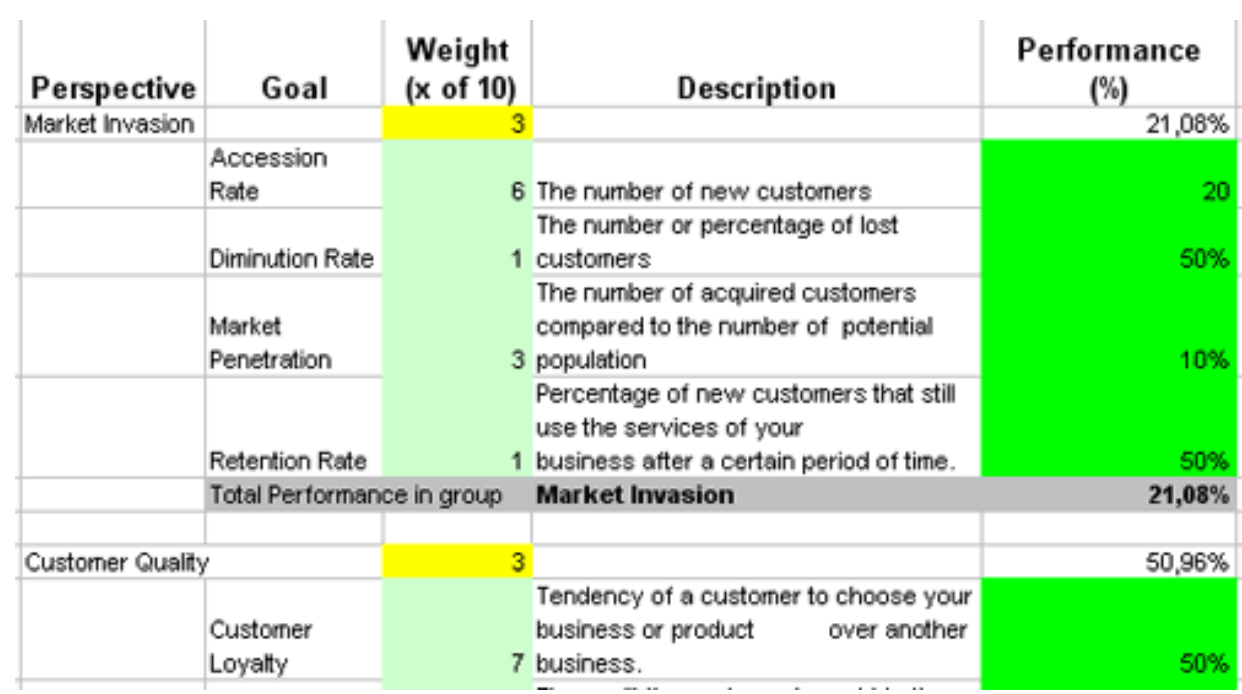

Obr. 1 - Príklad hodnotenia CRM pomocou Balanced Scorecard [1]

Použitie CRM Scorecard je relatívne jednoduché. Najzložitejšia je úvodná fáza, kedy je potrebné zadat' vstupné nastavenia, zvolit' najhlavnejšie aspekty CRM a priradit' všetkým aspektom príslušnú váhu. Taktiež t’ažšie zrozumitel'né informácie a požiadavky môžu komplikovat' používanie tejto metodiky [8].

\section{Model pre hodnotenie efektívnosti CRM podl'a autorov Kim, Suh a Hwang}

Autori Jonghyeok Kim, Euiho Suh a Hyunseok Hwang si ako základ svojej metodiky pre meranie efektívnosti CRM zobrali spomínaný Balanced Scorecard. Pozmenili však definované 4 perspektívy na svoje vlastné, konkrétne:

- Znalost' zákazníka (Customer Knowledge)

- Interakcia so zákazníkom (Customer Interaction)

- Hodnota zákazníka (Customer Value)

- Zákaznícka spokojnost' (Customer Satisfaction) [5]. 


\section{Metodika merania CRM v organizáciách podl'a autorov Storbacka a Lehtinen}

Fínski autori Kaj Storbacka a Jarmo R. Lehtinen vo svojej publikácii Řizení vztahů se zákazníky ponúkajú spôsob hodnotenia systému CRM a jeho fungovania.

Ide o súbor tabuliek dotazníkovej formy, kde respondent odpovedá na zadané otázky, týkajúce sa jednotlivých aspektov systému CRM. K dispozícii má možnosti „ÁNO“ a „NIE“. Vyhodnotenie dotazníka je subjektívne, ked’že táto metodika má slúžit' len pre akési uvedomenie si fungovania systému CRM. Na základe týchto odpovedí respondent sám hned' zistí, ktoré aspekty CRM sám spĺn̆a a ktoré zatial' nie. Následne môže pristúpit' k jeho zdokonaleniu v daných oblastiach [11].

\section{Metóda hodnotenia CRM - CRMBodyCheck}

Metóda CRMBodyCheck pracuje s 5 základnými elementmi CRM: zákazník, stratégia, l'udia, proces a technológia. Každý z týchto elementov ponúka v sebe niekol'ko metrík, pomocou ktorých sa uskutočňuje hodnotenie CRM.

Konkrétny obsah jednotlivých elementov a ich metrík je popísaný v nasledujúcej tabul'ke:

Tab. 2 - CRMBodyCheck [7]

\begin{tabular}{|c|c|}
\hline Elementy & Metriky \\
\hline \multirow{4}{*}{ Zákazník } & LOJALITA (Loyalty) \\
\hline & INTELIGENCIA (Intelligence) \\
\hline & HODNOTA (Value) \\
\hline & SKÚSENOSŤ (Experience) \\
\hline \multirow{3}{*}{ Stratégia } & VÍZIA (Vision) \\
\hline & STRATÉGIE (Strategies) \\
\hline & $\begin{array}{l}\text { METRIKY CIELOV A VÝKONNOSTI } \\
\text { (Objectives and Performance Metrics) }\end{array}$ \\
\hline \multirow{3}{*}{ Ludia } & MANAŽMENT ZMIEN (Change Management) \\
\hline & Employee Buy-in \\
\hline & ORGANIZAČNÁ ŠTRUKTÚRA (Organizational Structure) \\
\hline \multirow{3}{*}{ Proces } & INFORMAČNÝ TOK (Information Flow) \\
\hline & TVORBA PROCESU (Process Design) \\
\hline & ORGANIZAČNÉ ZARADENIE (Organizational Alignment) \\
\hline \multirow{4}{*}{ Technológia } & MAPOVANIE POŽIADAVIEK (Requirements Mapping) \\
\hline & $\begin{array}{l}\text { INTEGRÁCIA A KOMPATIBILITA } \\
\text { (Integration and Compatibility) }\end{array}$ \\
\hline & VOL'BA PREDAJCU (Selection of Vendor) \\
\hline & HODNOTENIE (Evaluation) \\
\hline
\end{tabular}

\section{Customer Relation Analysis Complex Kit (Metóda CRACK)}

Autorom tejto metódy je Ing. Vít Chlebovský, Ph.D. z Fakulty podnikatelské - Vysoké učeni technické v Brne. V rámci svojej práce vytvoril konkrétny systém merania úrovne CRM, tzv. CRACK Model (Customer Relation Analysis Complex Kit).

Základom pre akékol'vek d'alšie detailnejšie hodnotenie, nielen systému CRM, je dôsledné poznanie súčasného stavu firmy. Ide o klasické dotazníky, ktoré sú zamerané na 
poznanie interného prostredia podniku a taktiež aj na externé prostredie, v ktorom sa podnik nachádza a ktoré na neho vplýva.

Samotné hodnotenie systému CRM prostredníctvom metódy CRACK začína výberom vhodných veličín, ktoré najlepšie charakterizujú systém CRM. Každý podnik si zvolí individuálny súbor veličín, ktorý najlepšie vystihuje jeho charakter činnosti.

Metóda CRACK ponúka na výber relatívne širokú škálu takýchto veličín, ktoré sú zoskupené do 9 skupín:

Tab. 3 - Sledované veličiny v metóde CRACK [4]

\begin{tabular}{|c|c|}
\hline Skupina & Veličina \\
\hline \multirow{3}{*}{ Marketing - značka } & Povedomie o značke (Brand Awareness - BAW) \\
\hline & Kvalita značky (Brand Quality - BQU) \\
\hline & $(\mathrm{Ne})$ lojalita ku značke (Brand Loyalty - BLO) \\
\hline \multirow[t]{2}{*}{ Marketing-ponuka } & Hodnota ponuky (Value Equity - VEQ) \\
\hline & Spokojnost' s ponukou (Value Satisfaction - VSA) \\
\hline \multirow{4}{*}{ Marketing - kampan̆ } & Dosah kampane $($ Reach - CRE) \\
\hline & Reakčné percento (Response Rate-CRR) \\
\hline & Konverzia (Conversion Rate - CCR) \\
\hline & Náklady na kampaň (Campaign Cost - CCO) \\
\hline \multirow{6}{*}{$\begin{array}{c}\text { Marketing - } \\
\text { internetové aktivity }\end{array}$} & Počet návštevníkov (Visitor Count - IVC) \\
\hline & Počet jedinečných návštevníkov (Unique Visitor Count - IUV) \\
\hline & Obl'úbené stránky (Page Hits - IPH) \\
\hline & $\begin{array}{c}\text { Priemerná doba strávená návštevníkom prehliadaním internetovej } \\
\text { prezentácie (Duration - IDU) }\end{array}$ \\
\hline & Registrovaní používatelia (Registered Users - IRU) \\
\hline & Percento prerušení (Breakage - IBR) \\
\hline \multirow{14}{*}{ Sales - zákazníci } & $\begin{array}{l}\text { Náklady na získanie nových zákazníkov } \\
\text { (Customer Acquisition Cost - SAC) }\end{array}$ \\
\hline & Pravdepodobnost' úspechu (Close Percentage - SCP) \\
\hline & Priemerná vel'kost' objednávky (Average Order Size - SAO) \\
\hline & Priemerný podiel z rozpočtu (Share of Wallet - SSW) \\
\hline & Výsledky predaja (Sales Totals) \\
\hline & Zisk na zákazníka (Customer Profit - CUP) \\
\hline & Tržby na zákazníka (Customer Sales - CUS) \\
\hline & Obrat zásob (Turn on Inventory - TOI) \\
\hline & Obrat pohl'adávok (Turn on Account Receivables - TOR) \\
\hline & $\begin{array}{l}\text { Počet zákazníkov v najvyššom rade obratu } \\
\text { (Top Customers - TOC) }\end{array}$ \\
\hline & $\begin{array}{c}\text { Počet zákazníkov s obratom «1/10 najvyššej skupiny } \\
\text { (LowEnd Customers - LEC) }\end{array}$ \\
\hline & Štatistika kontaktov so zákazníkmi (Customer Contact Statistics) \\
\hline & Efektivita osobného kontaktu (Meeting efficiency - MEF) \\
\hline & Efektivita elektronického kontaktu (Call efficiency - CEF) \\
\hline \multirow{5}{*}{$\begin{array}{l}\text { Zákaznícka podpora - } \\
\text { Call Centrum }\end{array}$} & $\begin{array}{c}\text { Počet telefonátov a ich dížka } \\
\text { (Call Counts and Duration - CCO, CDU) }\end{array}$ \\
\hline & Priemerná čakacia doba (Average Hold Time - CHT) \\
\hline & Počet prerušených telefonátov (Abandonment Rate - CAR) \\
\hline & Priemerný čas do prerušenia (Average Abandonment Time - CAT) \\
\hline & Čas zhrnutia (Wrap-up Time - CWT) \\
\hline
\end{tabular}




\begin{tabular}{|c|c|}
\hline & Priemerné náklady na hovor (Average Cost per Call - CAC) \\
\hline & Priemerná doba hovoru (Average Talk Time - CTT) \\
\hline & Priemerná doba vysporiadania (Average Handle Time - CDT) \\
\hline & Počet blokovaných hovorov (Blocked Calls - CBC) \\
\hline & Výkonnost' Call Centra (Service Level - CSI) \\
\hline \multirow{4}{*}{$\begin{array}{c}\text { Zákaznícka podpora - } \\
\text { servis }\end{array}$} & Reakčná doba (Response Time - SRT) \\
\hline & Doba servisného úkonu (Repair Fulfillment Time - SFT) \\
\hline & Celková doba servisného zásahu (Completion Time - SCT) \\
\hline & $\begin{array}{l}\text { Úroveň spokojnosti zákazníkov so servisom } \\
\text { (Customer Satisfaction Score - SSS) }\end{array}$ \\
\hline \multirow{8}{*}{ Logistika } & Miera splnenia objednávky (Fill Rate - LFR) \\
\hline & Dodržanie požadovaného termínu (In Time Ship Rate - LOS) \\
\hline & Dodržanie slúbeného termínu (Performance to Promise - LPS) \\
\hline & Percento nesplnených objednávok (Backorders - LBO) \\
\hline & $\begin{array}{l}\text { Doba potrebná k realizácii objednávok } \\
\text { (Customer Order Cycle Time - LCT) }\end{array}$ \\
\hline & Finančný cyklus objednávky (Cash to Cycle Time - LCC) \\
\hline & Celková zásobovacia perióda (Supply Chain Cycle Time - LST) \\
\hline & Spol'ahlivost' procesu (Perfect Order Measure - LPO) \\
\hline \multirow{4}{*}{$\begin{array}{l}\text { Komplexné } \\
\text { ukazovatele }\end{array}$} & Rentabilita nákladov (Return on Cost - ROC) \\
\hline & Rentabilita tržieb (Return on Sales - ROS) \\
\hline & Zisk na zamestnanca (Employee Profit - EMP) \\
\hline & Tržby na zamestnanca (Employee Sales - EMS) \\
\hline
\end{tabular}

K vybraným veličinám sa následne vykoná priradenie váh podl’a dôležitosti konkrétnej veličiny, tzv. váhovanie. Kvalitne vykonané váhovanie je dôležitým krokom konkrétneho systému merania úrovne CRM v danom podniku. Vzhl'adom na to, že ide do značnej miery o subjektívny proces, je dobré, aby svoje návrhy na priradenie váh predložilo viac manažérov na rôznych úrovniach riadenia firmy a následne boli ich návrhy zjednotené (napr. bežným priemerovaním).

Ďalším krokom je vytvorenie tzv. vyhodnocovacej tabul'ky, do ktorej sa bude pre každý ukazovatel' zadávat' jeho hodnota. Táto hodnota sa vynásobí váhou a prepočíta sa na percentá (vid’. Obrázok č. 2).

\begin{tabular}{|c|c|c|c|c|c|c|c|c|c|c|c|c|}
\hline Oblast & Veličina (označeni) & Popis & Vzorec pro výpočet & $\begin{array}{l}\text { Minimální } \\
\text { hodnota }\end{array}$ & $\begin{array}{c}\text { Maximál } \\
\text { ni } \\
\text { hodnota }\end{array}$ & Jednotka & $\begin{array}{l}\text { Optimálni } \\
\text { rozsah } \\
\text { hodnot }\end{array}$ & $\begin{array}{c}\text { Skutečná } \\
\text { (změrená) } \\
\text { hodnota }\end{array}$ & $\begin{array}{l}\text { Procentuâlni } \\
\text { prepočet k } \\
\text { pripustnému }\end{array}$ & Váha & $\begin{array}{l}\text { Priepočten } \\
\text { à hodnota }\end{array}$ & $\begin{array}{l}\text { Jak } \\
\text { casto } \\
\text { sledu }\end{array}$ \\
\hline \multirow[t]{5}{*}{ Marketing-značka } & povédomi (BAW) & jak je značka vnímána & | (značku znaji// všsichni & 0 & 100 & $\%$ & $65+$ & & hodnota / $/ \max -\min \mid$ & & 0 & rok \\
\hline & \multirow[t]{3}{*}{ kvalita (BQU) } & \multirow{3}{*}{$\begin{array}{l}\text { jajke kvalita zzačch } \\
\text { vnimána zákazniky? }\end{array}$} & 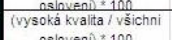 & 0 & 100 & $\%$ & $\frac{\operatorname{maximajizacel}}{60+}$ & & hodnota $/[\max -\min \mid$ & & 0 & \\
\hline & & & 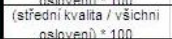 & 0 & 100 & $\%$ & 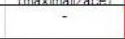 & & hodnota / / $\max -\min \mid$ & & 0 & rok \\
\hline & & & (nizkák kvalta / všschni & 0 & 100 & $\%$ & 15-(minimalizace) & & $(\max -\min \mid-h) / \max -\min \mid$ & & 0 & \\
\hline & (ne) ) lojajitta (BLO) & 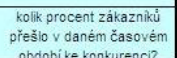 & 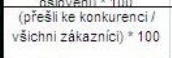 & 0 & 100 & $\%$ & 3-(minimalizace) & & $(\max -\min \mid-h) / \max -\min l$ & & 0 & rok \\
\hline \multirow[t]{6}{*}{ Marketing-nabídka } & \multirow[t]{3}{*}{ hodnota (VEQ) } & \multirow[t]{3}{*}{ 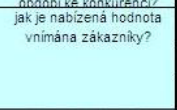 } & 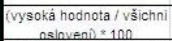 & 0 & 100 & $\%$ & $\frac{60+}{6 \text { maximalizace) }}$ & & hodnota $/|\max -\min |$ & & 0 & \\
\hline & & & istréedni hodnota / všschni & 0 & 100 & $\%$ & & & hodnota / / $\max -\min \mid$ & & 0 & $\overline{r o k}$ \\
\hline & & & $\begin{array}{l}\text { (nizká hodnota / / všichni } \\
\end{array}$ & 0 & 100 & $\%$ & 15- (minimalizace) & & $(\max -\min \mid-h) / \max -\min \mid$ & & 0 & \\
\hline & \multirow[t]{3}{*}{ spokojenost (VSA) } & \multirow[t]{3}{*}{$\begin{array}{l}\text { Jak jsou zákaznicis } \\
\text { nabidkou spokojeni? }\end{array}$} & 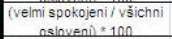 & 0 & 100 & & $\begin{array}{c}65+ \\
\text { (maximalizace) }\end{array}$ & & hodnota $/|\max -\min |$ & & 0 & \\
\hline & & & 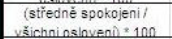 & 0 & 100 & $\%$ & & & hodnota / /max - min| & & 0 & rok \\
\hline & & & 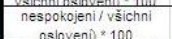 & 0 & 100 & $\%$ & 8-(minimalizace) & & $([\max -\min \mid-h) / \max -\min \mid$ & & 0 & \\
\hline \multirow[t]{3}{*}{ Marketing-kampañ } & dosah (CRE) & $\begin{array}{c}\text { jaké procento z } \\
\text { oslovených zákaznikú } \\
\text { kamnañ zarenistrovalo? }\end{array}$ & $\begin{array}{c}\text { (zaregistrovali / / šichni } \\
\text { os loveni) }=100\end{array}$ & 0 & 100 & $\%$ & $\begin{array}{c}40+ \\
\text { (maximalizace) }\end{array}$ & & hodnota / $/ \max -\min \mid$ & & 0 & kampe \\
\hline & reakčni faktor (CRR) & $\begin{array}{l}\text { Jaké procento } z \\
\text { oslovených zákaznikủ na } \\
\text { kamnaó zareanouala? }\end{array}$ & & 0 & 30 & $\%$ & $5+$ (maximalizace) & & hodnota / / $\max -\min \mid$ & & 0 & kampe \\
\hline & konverze (CCR) & 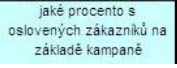 & $\begin{array}{l}\text { (nakoupili/ ivăichni } \\
\text { osloveni) } * 100\end{array}$ & 0 & 7 & $\%$ & $2+$ (maximalizace) & & hodnota $/ \mid \max$ - $\min \mid$ & & 0 & kampe \\
\hline
\end{tabular}

Obr. 2 - Vyhodnocovacia tabul'ka používaná pri metóde CRACK [4] 
Z takto získaných hodnôt následne vytvoríme váhový priemer a získame jednotnú percentuálne vyjadrenú úroveň CRM, pričom 100\% je akýsi teoretický ideálny stav [4].

\section{Záver}

Pri porovnaní týchto metód je potrebné brat' do úvahy typ veličín, ktoré skúmajú. Metódy, ktoré sú zamerané na tvrdé metriky (zväčša finančné ukazovatele), poskytujú jasné exaktné výsledky. V prípade hodnotenia úspešnosti CRM ide o ukazovatele ROI, ROC, ROS, EMP, a EMS. O správnosti a objektivite ich výsledkov nie je možné pochybovat'. Existuje však množstvo ukazovatel'ov, ktoré nie je možné vyjadrit' tvrdými metrikami. V značnej miere je to zrejmé práve pri hodnotení systémov CRM, ktoré vo svojej podstate súvisia s l'ud'mi a vzt'ahmi medzi nimi. Pre ich vyjadrenie existuje niekol'ko metód a metodík, ktoré sú popísané vyššie a ktorým sa podstatnou mierou venuje táto dizertačná práca.

Väčšina takýchto metód je založená na báze dotazníkových prieskumov medzi dotknutými manažérmi. Ich spoločným znakom je teda najmä subjektivita získaných výsledkov. Taktiež každé takéto meranie musí byt' realizované pravidelne. Jednorazové vyhodnocovania nemajú vel'ký význam, pretože sa nimi nedá preukázat' napredovanie, resp. stagnácia v danej oblasti. Odporúčaným intervalom takéhoto hodnotenia je, podobne ako pri iných vyhodnocovaniach, obdobie jedného roka.

Podl'a Petra Kopřivu sú podniky rozdelené do 5 úrovní podl'a stavu CRM. Táto identifikácia je realizovaná prostredníctvom vopred definovaných charakteristických znakov. Ide o vel'mi jednoduchú metódu.

CRM Maturity Model je realizované na podobnom princípe. Sú definované 3 hlavné skupiny, $\mathrm{v}$ rámci ktorých sa nachádza 6 stupňov úrovne CRM. Každý z týchto stupňov má vopred predpísané charakteristiky, podl'a ktorých sa podnik zaradí do konkrétnej skupiny.

Metóda CRM Scorecard vychádza z úspešnej koncepcie Balanced Scorecard, ktorá má definované 4 perspektívy hodnotenia, pričom neobsahujú iba finančné ukazovatele, ale aj ukazovatele mäkkých metrík. V súčasnosti je realizácia tejto metódy automatizovaná a je možné ju vykonávat' prostredníctvom softvérových riešení. CRM Scorecard zároveň poukazuje na rozdielnost' úrovní, na ktorých sa CRM vyhodnocuje. Iné výsledky je možné dosiahnut' pri hodnotení CRM na strategickej úrovni podniku ako napr. na úrovni divízie alebo tímu.

Autori Kim, Suh a Hwang si zobrali za základ ich CRM Scorecard, pričom pozmenili 4 perspektívy. Všetky ich 4 perspektívy sú orientované výlučne na zákazníka.

Fínski autori Storbacka a Lehtinen pomenovali aspekty CRM, podl'a ktorých si manažér dokáže vytvorit' vlastný názor na súčasný stav CRM v podniku, odhalit' prípadné nedostatky a vykonat' ich nápravu.

Metóda CRMBodyCheck je oproti ostatným metódam prepracovanejšia. Definuje 5 základných elementov CRM, ktoré v sebe obsahujú d'alšie kritériá a metriky, ktoré určujú ich úroveň. Zväčša ide o subjektívne ukazovatele, ktoré správne zvoleným váhovaním vyjadrujú celkovú percentuálnu úroveň CRM v danom podniku.

Metóda Víta Chlebovského pod názvom Customer Relation Analysis Complex Kit (CRACK) je podstatou a princípom podobná predchádzajúcej metóde CRMBodyChceck. Má však preddefinovaných až 9 hlavných oblastí, v rámci ktorých sa nachádzajú konkrétne kritériá a metriky. Manažér si sám zvolí, ktoré kritériá chce vyhodnocovat' a akú váhu/dôležitost' im priradí. Samotné vyhodnotenie je realizované v tabul'kovej forme v programe Microsoft Excel a výsledkom je percentuálne vyjadrená celková úroveň CRM.

Žiadna zo spomenutých metód a metodík priamo nedáva do súvisu CRM a oblast' inovácií, projektového riadenia a podnikovej kultúry. Samozrejme, určité individuálne 
charakteristiky týchto oblastí je možné nájst' v niektorých uvedených metódach (napr. oblast' inovácií je čiastočne popísaná v metóde CRMBodyCheck alebo niektoré charakteristické znaky podnikovej kultúry je možné nájst' v metóde CRACK). Nikde však nie sú pomenované, popísané a definované jednoznačne a komplexne, čo bude predmetom návrhovej časti doktorandskej dizertačnej práce Ing. Petra Mišáka na MTF STU v Trnave.

\section{Literatúra}

[1] AKS Labs: Customer Relationship Balanced Scorecard Metrics Template. [online] [cit 2009-10-11]. Dostupné na internete: $<$ http://www.strategy2act.com/solutions/customer_relationship_excel.htm>.

[2] Close, W. S. a kol.: CRM at Work: Eight Characteristics of CRM Winners. [online] [cit 2009-10-11]. Dostupné na internete $<$ http://www.gartner.com/DisplayDocument?doc_cd=98877>.

[3] Dohnal, J.: Rízení vztahů se zákazníky - Procesy, pracovníci, technologie. Grada Publishing, Praha, 2002, 164 s., ISBN 8024704013

[4] Chlebovský, V.: CRM - Řízení vztahů se zákazníky. Computer Press, Brno, 2005, 190 s., ISBN 80-251-0798-1

[5] Kim, J., Suh, E., Hwang, H.: A Model for Evaluating the Effectiveness of CRM Using The Balanced Scorecard. [online] [cit 2009-10-11]. Dostupné na internete: $<$ http://mis.postech.ac.kr/research/Full/A\%20model\%20for\%20evaluating\%20the\%20 effectiveness\%20of\%20CRM\%20using\%20the\%20balanced\%20scorecard.pdf>.

[6] Kopřiva, P.: Inovace řízení vztahu se zákazníky. Doktorská disertační práce, Fakulta informatiky a statistiky VŠE, Praha, 2001

[7] Lee, S.: The CRM Evaluation Method - CRMBodyCheck. [online] [cit 2009-10-11]. Dostupné na internete: <http://www.crmexcellence.nl/crm\%20\%20artikelen/the\%20crm\%20body\%20check.pdf>.

[8] Miller, S.: Customer Relationship Management And The CRM Scorecard. [online] [cit 2009-10-11]. Dostupné na internete: <http://articles.exospy.com/businessmanagement/customer-relationship-management-and-the-crm-scorecard.html $>$.

[9] O’Conner, A.: Must Haves v/s Nice to Haves, Part 2. [online] [cit 2009-10-11]. Dostupné na internete: <http://www.clickz.com/crm/crm_strat/article.php/900731>.

[10] Robinson, J.: A step-by-step guide to Successful CRM. [online] [cit 2009-10-11]. Dostupné na internete: <http://www.crm-forum.com/library/art/art-088/>.

[11] Storbacka K., Lehtinen, J. R.: Ř́ízení vztahů se zákazníky. GRADA, 2002, 168 s., ISBN 807169813X

[12] Strenitzerová, M.: Prínos a význam CRM pri zvyšovaní efektívnosti vybraného siet'ového podniku. [online] [cit 2009-10-11]. Dostupné na internete: $<$ http://ks.utc.sk/casopis/pdf/III2006/strenitzerova.pdf $>$.

[13] Tóth, A.: Implementácia Balanced Scorecard. [online] [cit 2009-10-11]. Dostupné na internete:

$<$ http://www.systemonline.cz/clanky/implementacia-balancedscorecard.htm>.

\section{Grantová podpora}

"Tento príspevok vznikol v rámci projektu VEGA č. 1/0491/09, interné číslo 1489." 